\title{
Addressing Human Rights Concerns after Korean Reunification
}

\author{
JON M. VAN DYKE

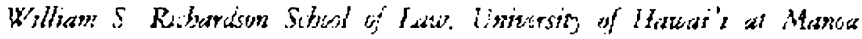

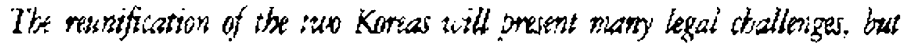
sue of the mast profound is bra to deut with the buman nzbt: abuses that

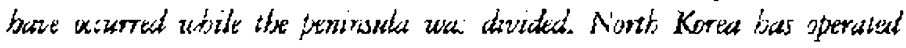

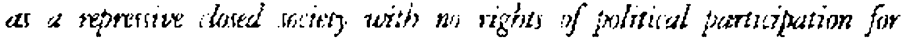
its citizens, one! punishments of dissentan, derials of minimum buman needs

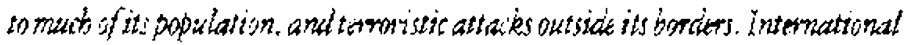
law now reognizer ibe right of vistims of buman rights abutes to a jull

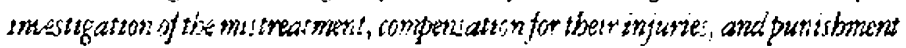

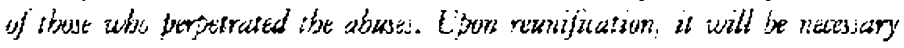

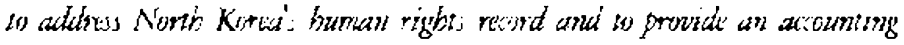
and a proper clowe for tho miaim:
\end{abstract}

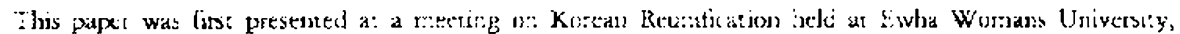
Serul on Novemixi 10. 2031.

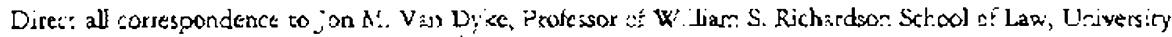

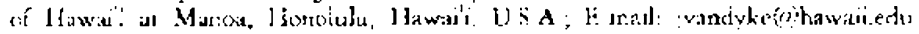




\section{INTRODLCIION}

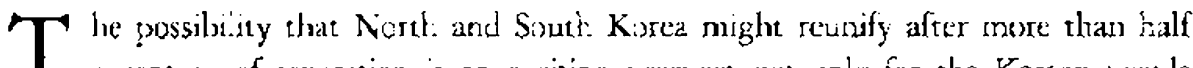
1 a centaly of separation is an exciting proxpxyt not only for the Korean people but for everyone working roward a peaceful, prosperous, and just workd. The opportunity ro erable the talented and hard-working Koreans to work togerner to strengthen their culure and economic development is one that snoudd be pursued with vigor. But difficulties will inevitabiy present thernselves ieganding how to reconcile the sharply contrasting 'egal and economic systems, and it is app:opriate to examine some of the fundamenta questions that will aeed tc be sored out during the reunification process.

What shoud be done with conlicting and overapping property elimis? What about the diffeule situations crea:ed by Koteans in divided families who may have spouses and children in both Nomb an: South Kraen: Will all Nimth Koreans have the right to reirate to the South. where johs and entrepneneurial artivities wili to grearer? Will this right of "return" te tecognized immediately or only after formal reunification is accomplished? How will the property and oche: civil righes of North Koreans who move Sourh be acjusted? Wil' South Koreans have the right to invest in the North, or will some limits be imposed :o protect the Nerth Korean incustres? Will North Korean industries remain state-owneci and centrally managed, or will nosi of them beconle privatized? If so, what wil the process of privatization leok likc?

'Ihese questions presert enormous difficul:ies, which may requine many meterings and detailed discussions to son out. This patxer is dexigned on promene sonx of the neressary disctissin by focusing on one aspert of th:s challenge what are the ramufications urder interational law of the maprothement between Nort: and Susth Korea in light of the human rights abuses ansi at:ocities that have xxcurred during the decades of separation?

\section{LNRESOLVED KOREAN HLMAN RIGH'IS ABUSES}

During the hale ewitury of tension or the Kcrean penirsula many unresolved humiut raghes alouses have occursed rhar remain to ix sorted our. The' Democratir People's Republic of $\mathrm{Ku}$ (ca (North Kn-aa) has been run by a righrly discriplined aithorita:ian regime, which prevented any chal.enges :O its control as well as prohibited anything resembling tree eleciors o: multi-pary democracy o: any form of :eal participation in decision-making by its citize.zs. "IIhn a socie:y sthere the multi- parry system is regarded as a taboo, there will be neither freedom of political activities nor freeden of thought,

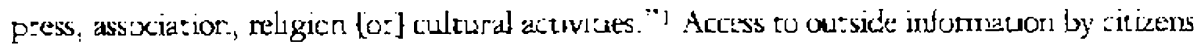

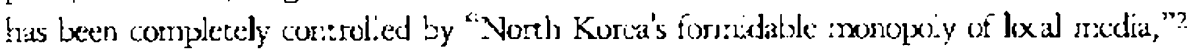

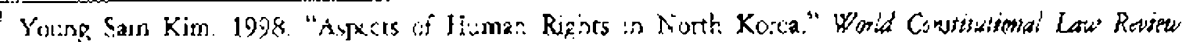
395, voi. 3: 404 .

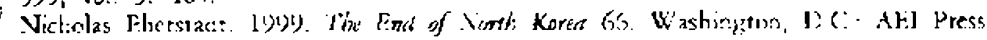


ard the governmen's primaty relasionship with its cirizens is aimed "at successfully indoxiniating the perole with comrnuristic ducals."3 instead of recogrizing and protecting the human aghes of its citizeas, Nerth Korea em:- hasizes their duties to the state, which "take prioriry over rights." "In North Ko-ca inalizenable human rights are non-existent and the poople bave the disty to realize the puspose and ideal of buiding the sxialist state urder the dictaroship of the proletrriat." The centalized econcaic system, combines with an unraverung commitment to maintain an extraordinarily large military force catier than frovide guods for consumers, has led to repeated shor:ages of bask commodiries, including sulficient food, especially since 1y95.'

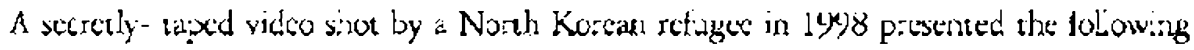
distressing wenes:

IR: are fout ofthans sucking stshtones in a squaild outdoot market; worxen picking lice from ach other's hain, men wading into a river to wh out the bodies of Frends whe starved to death ar were sho: by burde: guards.

In one scene, an cenaciateci boy stingers from nuriger as tine cameranan asks bira where he lives. The chid is ar: orphan and lives on what scraps he ran fird in the openec air market. He is cieariy cose to collapse. In another ha:rowing scene, a smali gi:! tries to scocp dirty water to drink from a puddle with. a plastic bag. Some $v$ ! the chilidren said tacy had run axay from stale-ru: "relief cerrires" wivere the ory food was two ladles of corm grued a day. In some cases their parents bart died ar pome away we searth fo: foxd and hever rame bas: ${ }^{8}$

A Korear Airlines 3oeing ?0? was bombed mid-air in 998,9 and a commando raid atcacked the South Korean Prexiden in Sevul, apparently the work of Norh Korean agunts. 11 Ten of irore unsolved kidnappings have occurred in Japan attributable to North Korear. agents, ${ }^{11}$ and Souch Korea has repored nore than 400 cases of suspected

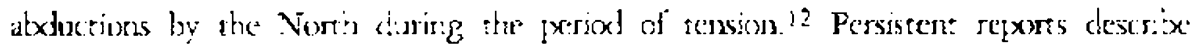
eximjudicial killings, disippxarances, and prolonged arlsitary derention by the North Korean government. $: 3$ Exer.tions reporedly include senior party nembers and military

Kim, supres noil ?. p. 39 )

$4,4,2 ; 01$.

id., 90.

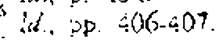

ebersiadt supra cote 3. p.3.

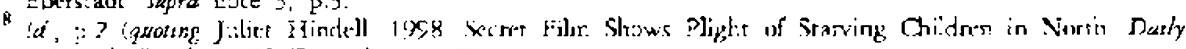
Telegetph (Locdon), 19 December, at 17):

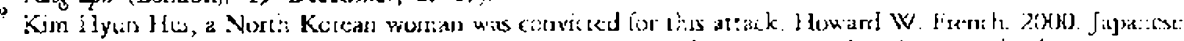

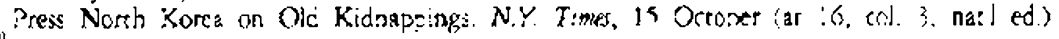

11) 1 (d.

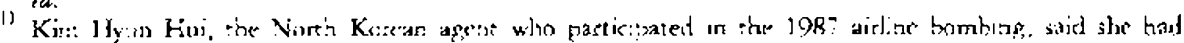

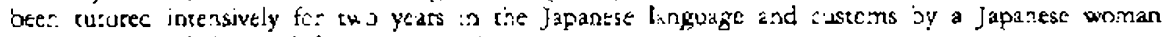
wile had lecen ksinapied from: Jayan. id

!2 id.

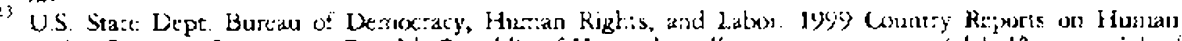

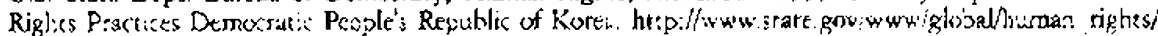

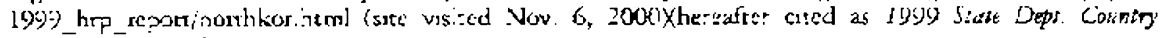
Roport or: North Kursi: 


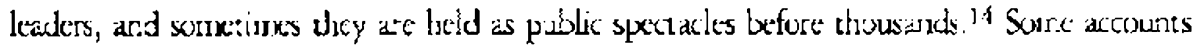
state that 150,000$)$ ro 200,000 persens are held in sarsin conditions in 12 North Korcan prison camps for political teascus. : North Korcais Penal Code imposes harsh "da. conian"le punishmerts, including dears, for "ant-tevolusionary crimes which oppose the stite sovereignty and the socialist system," surh as criticizing Kiñ Il Song or Kim Jong $1 \mathrm{l}$ or the socialist systen: 17 The Code c'assifies as "bight treason" the act "of Aleeing from Vorth Korea to South Kores or a thirc ccuntry, or surrende: and convert to enemy force, the:eby betraying the fatherland and the people." is Accounts of hash prisor. conditions in Vorth Korca arc common, ard particularly onerous conditions arc apparenty imposed on :hose prisoners who are uncoujerative. ${ }^{1}$

"The yeople of Nuath Korea have thus been cenced basic hunan righes fer two geacrations, including the sigh: to political partixpation and frec cxpression, as well as mirimal nutritional neerls. Rezorrs have axtimated riat mary kave died from numger ard thar at 'eas: 100,000 have fed to Chira in searth of food. 20 Observers have reported that North Koreans seeking to leave the country (sometimes in desperate search fo: fcod) have been shot at the North Korean borders with China and Russia.2I According to a receat report by Amrest; Intersational:

Those aughe by border guarsis or re:urned by the (hincse autheriitix were at ask of human rights violations. There were repors of detanees being sevecly beaten by North Korean security guards and sen: (1) unheated, overciowded proson camos with!ttle fooci. (W inters is. No.th Korea are zarsh with temperatives

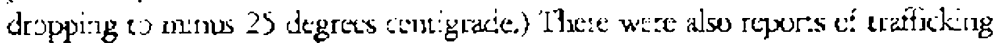
of wo:nern and girls in the iurcier arcia."

South Korea has also beer accused of hlimaa alghts violations, ircluding imposing long prison sentences or. its dissidents under Article 7 of its Nacional Security Lavi, ${ }^{23}$ In November 1999, the Human Rignts Committe in Gereva recommended that South Karea "phase out ti.e Varional Serurity Law" and ir particular to "urgently amend

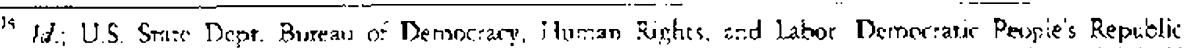

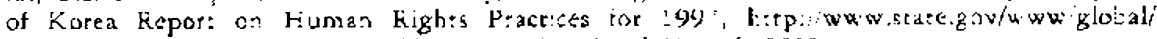

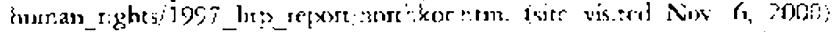

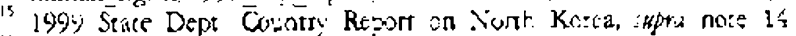

If Ciltin. sipte sule 2, is 424 .

M., F.

is. p. $41 \%$

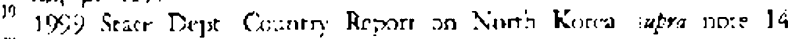

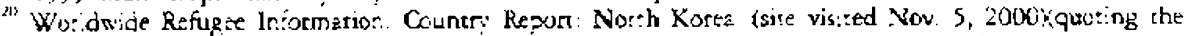

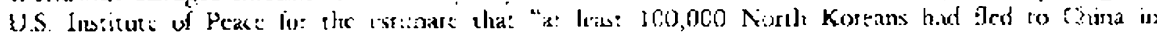

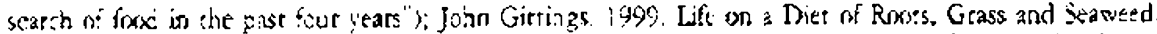

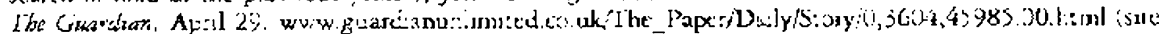

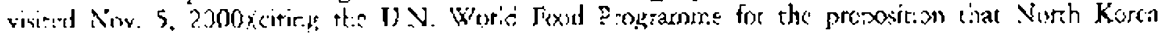
had "sirioly "nar. out of cood"

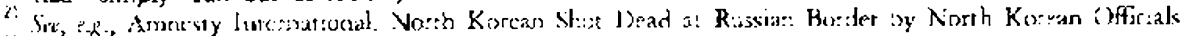
23 Id. Amnest; Ineerna: onai 5 Brnua. Re:xort 20C0).

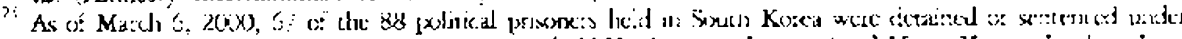

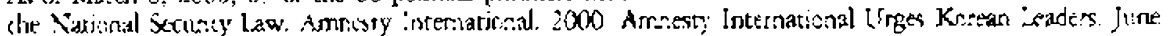

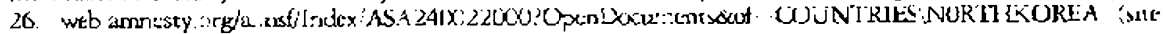
risited $\mathrm{N}(x)$ S. 2,00$)$
} 
Arricle 7 so as to rake it compativle wath the [lnternationas\} Covenant" on Civil and

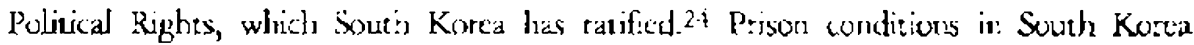
have: also bexn characterize: is "hard" 25 or "Spratan."25

These abuses mise scrious questions aixur: how the :xrotracors of the human rights vinlations should be treacod afrer reunitionion. In Novemixer 1999, the appeals courr in Ieipzig, Gerrany upheld a ma-sla:ghter conviction igainst Egon Krenz, the last

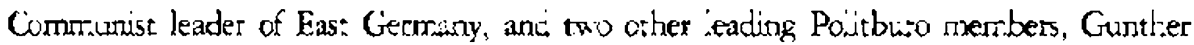
Kleiber and Gurther Schabowski, for their ro.es in the s:cortngs of persons tring to escape to the West ciuring the exrixd wines. Germany ruas divides. 27 Should the North

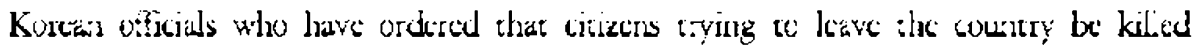
or brualized suffer tie sane tace? What about she soldiers who carried out these llegal

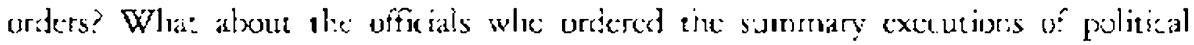
opyonnents? Respounsibility for such aterisions probalbly includes the highest learders in Nortt. Konea.

One wear preceden: was sstablished when Sout: Korea prosecuted and imprisoned two of its recent Presidents, Chun Dow Huan and Roh Tae Won, for acts of corruption and for human ights abusis in connection with the supp:ession of a rior, but an element of mercy was :atroduced when they were both reieased by prison by Kim Dat Jung shorry diter his election as Presidenc in 1997 as a gesture di nevional rcionciliation: 28

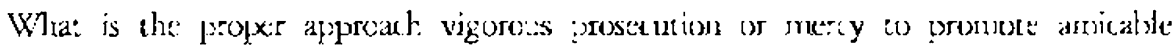

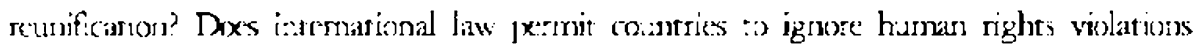
commitred by previcus regimes: The next secrion surveys the lawrs and practices on this subjest, anc deraonstrates that irterrarional law reculres proserurions arci civil remecies, but that councries have sometimes adapted this recurement to their specific needs in some tecen: situations to promote a com:zon effort to biald a unified nation.

\section{ITE RIGITI TO BRING A CLAIM IS A FUNDAMENTAL HUMAN RIGITT UNDER INTERNATIONAL LAW, AS IS TIIE DUTY TO PROSECUTE}

The right to bring a caim. for a violation of internationally-recognized human rights

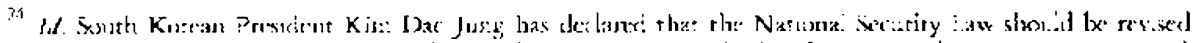
"to protect iuman rights and make the lav ccosistent with the Governments attempti to expand

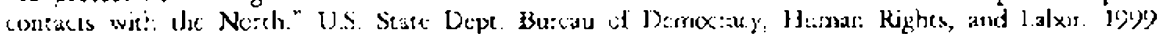

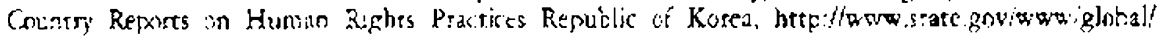

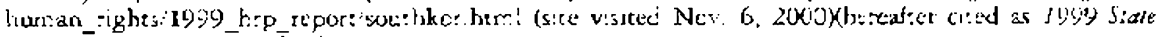

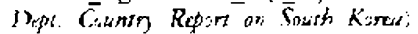

"Derechos:Hurnas Rights, Human Kig::s in. Souri Kurea nttp: 'uxw.derechos.org human-:ighrs'skerea.heml sitc visitid Nov. 6 , 20int?

2n 199\%; Sraie Dept Countri Rezort en South Korea, ispra noie 13

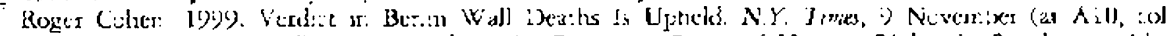

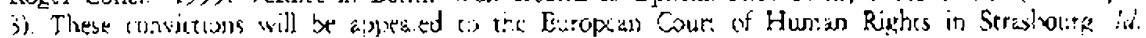

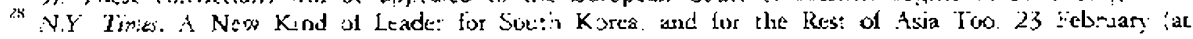

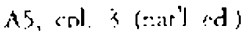


is well established under :necrnational iaw, and this ight includes lhe ablity to recoves monetiay contedsation, to insise on a proper and fuil investegation of the incident, and to sat ibe perpetrators of the abuses bromght to criminal :ustice. In artdition, the duries to investigate, prosecute, and compensate apply :3 a new surcessor government in the same fashion as tiey appy is the former government shat andertok or tolerated the human righ:s abuses.

Article 3 of the Universal Declaraion of Huran Rights29says that "Exeryone has the right to an efferite romet'y by the cor:petent ational tnburals for acts violating the tundamental rigints grantex hum by the constiturion or by law" (emphasis added). Similarly: Article 2(3)(a) of the lnternational Covenas: o: Civil and Polivica Rights, ${ }^{30}$

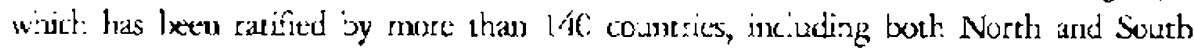

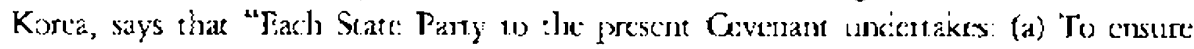
thar any zereson whose rights or ficertoms as herein recognizex are violated shal have an effective remzet, norwiths:anding tha: the violation has hean commirted by persons acting in an officia. capacioy..." (emphasis acided) 31

Regional human rights treaties also einphasize the ight to redress for hurnan rights violarions. Articie (xi) of tre Europear Conventicn on Human Rigkts" says that "In the cerermination of his civi! r:ghts..., everyone is entitled to a fair and public hearing within a reasonable cume by an indepencient and impartial tribunal estâjlisined by law."

Similarly, Artele 25(1) of the American Canvention on Human Rights 34 says that: Everyone has the r.ght to simple and prompt recourse, or any o:ier effective reco:use, to a competert court or trib:na for protection against

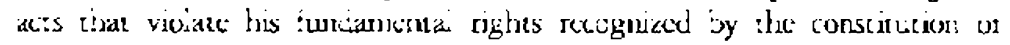

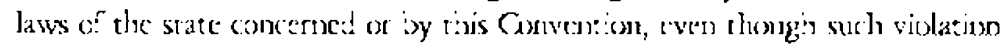
may have heen committed by persons acting in the rourse of apir offecial duries.

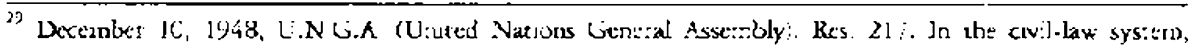

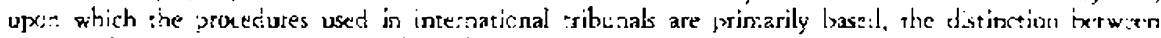
a crmiral pruseciorion anc a civil ciam or damages is not as sleas as :a is in the commun-jaw system

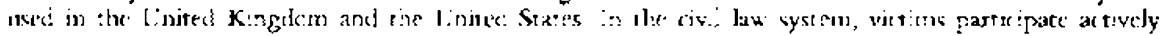
in criminal paxcedings and heip is prisenute them. For tha' reason, the rearess and drcisions that

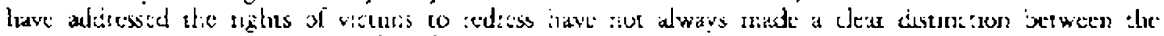

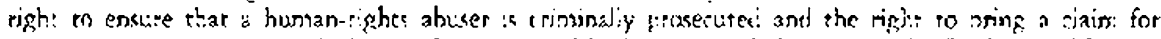

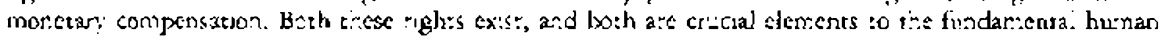

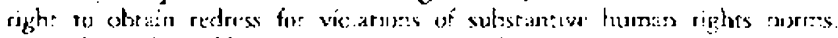

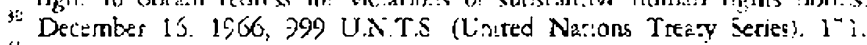

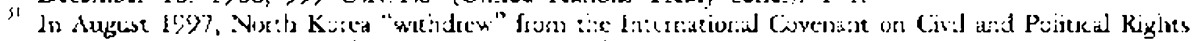

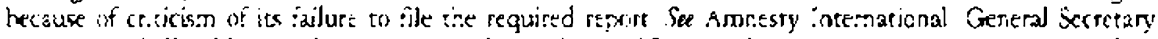

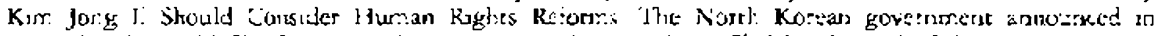

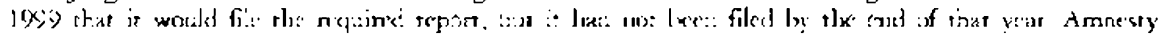

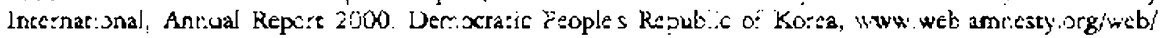

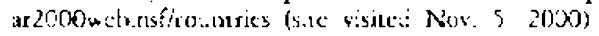

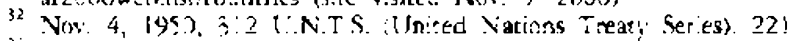

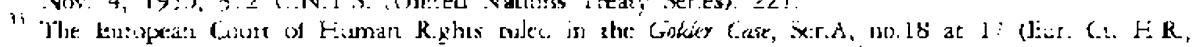

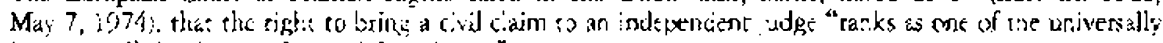
'recograzed" funciunce:tal seruceples of aw."

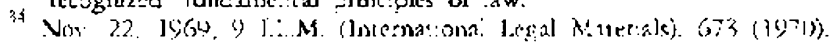


Deusions in the Inter-Anercar, system corfirm that the right to an effective remedy is a contrinuing one that arnot be wavex:. The seminal case of the Inter. Annerican Court of Human Rights is The Velauguez Rudriguez Caie, ${ }^{35}$ which holds that the American Convention on Human Righ:s imposes on earin state parry a "legal dury to eensure: the vicrim. andequate rompensation." The cours explained that each rouarry has the duty to protect the human righes listed in the Convention and articulated this resporsibi.ity as sollows:

This obligation implies the duty of the States paraes to orgarwe the

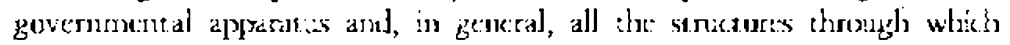
public nower is exercised, so thar they are capable of jicrioleally ensuring the free and full ecjoyment of humean :ights. As a cansequeace of this obligation, the States must prenent, imentigate and purish any violat:on of the rights :ecognized by the Cor:veritior..... 35

This decisior. is :mportant, because it lists both rine right to monetary comiensation and the right to see the perpetratons of àuses pinished as essential to the right to have cne's human rights protected. Similatily, the European Cout of Human Rights has ruied eecently tha: Turkey violated the righ:s of cirizens wao were preventec from bringing a claim for the deliberate destrucion of the: houses ard possession. notrrg that "ehe notion of an 'elfective remedy' entails, ir. addition to the paynent of compersation wh:cre approptiate, a thorough ance effective investigation capable of leading to the identification and punishrnen: of these respensibie and including effective access forr the

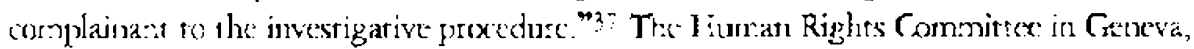
establisher' by the Intertaticnal Covenant on Cvil anc. Political Rights, has also gone on record opposing amnesties:

The Committee has noted that some States have granied aranasty in :espect

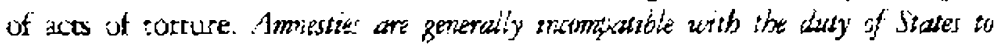

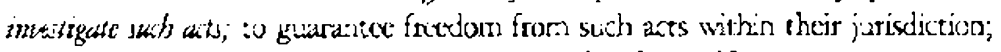
ani: ro ensure that they do not neclir in the fizure ${ }^{3 R}$

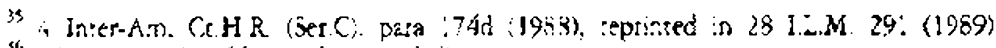

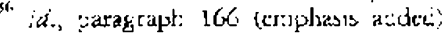

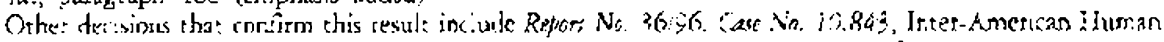

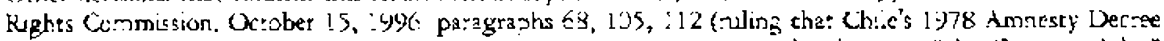

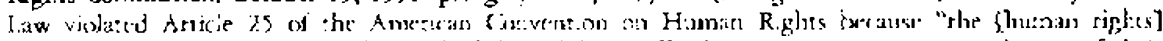
victims ant thair families were ceprived of the!? right to effective recuarse agarast the volat ons of their

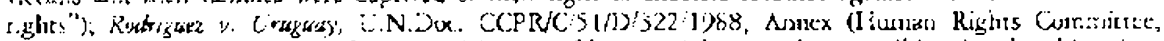

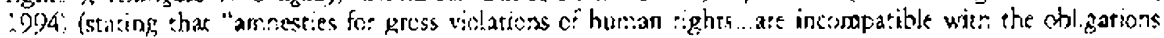

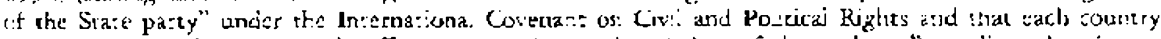

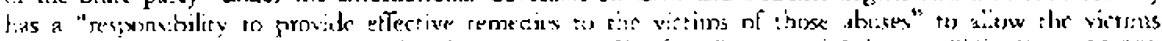

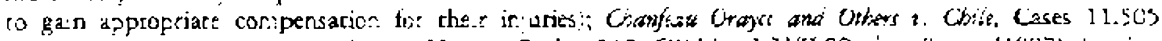

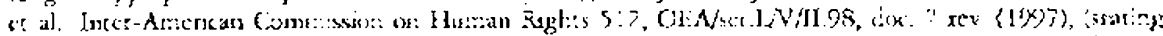

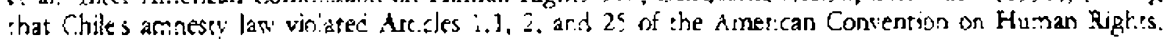

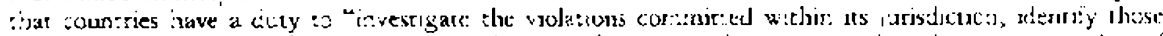

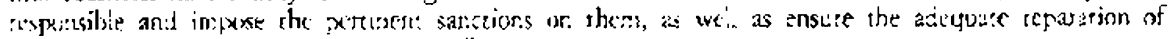
the conscquerses inftered by the mertm"),

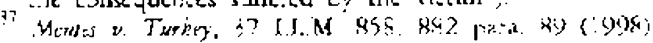


The right is pursue dains for compensation exists for wartime atrocites just as it exists for abuses that oceur in peactirne. ${ }^{39}$ I Jurnan rights ane not susperded during wartinx; indec: if woud be rcjelene to nold that responsibility is sacrificed when the

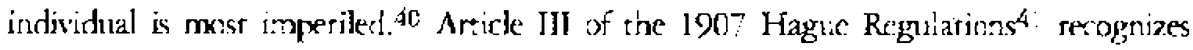
the duty to compensate for injuries caused curing war in the following language: ${ }^{*} A$ belligerent party which violates the provis:ons of the said Regukarions sinall, if the case demands, be liable to pay compersation. It shall be responsible for all acts committed by perscos forring pat of its arred corces." The Ireaty of Versailles 42 implemented thas requitement by cstablshing mixed arbitration tribunais for paivate ciamants to prescnt :heir damages aga:ase Germa:xy, even againse the wishes of their own goverramerots. These prikiples were codifiec once again ix: the Geneva Conventions of 1949

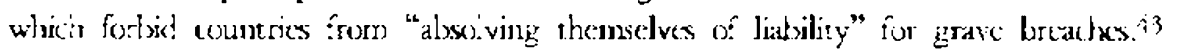

It is clear, therefore, tha: claims based on violarions of law are a form of property that cannor be cavaliery naved by a naton to serve some orher foreign polin; goal. Clainss basec on toriure, murder, pinysical abuse, acial persentricn, and other violations of bisic norms of zuman decency are particularly importank, and both international and U.S. law explicirly prctecis those claims aganst government neglect, duplicity, or abust. I'catles and amzesty agreernents purperting to waive claims or exonerate human righes abuses thus have no more valicity than the eflorts by the Chilean govenument

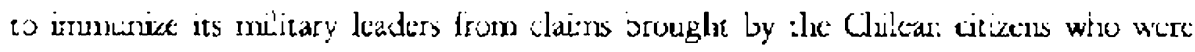

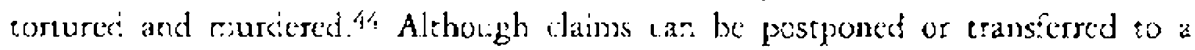

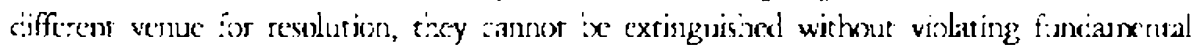
principles o: international law as wel. as basic precepts of faimess.

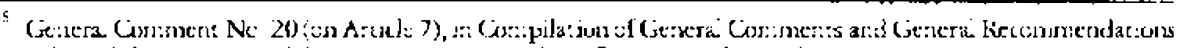
Acioprec by Human Righrs Teeaty Bosies, U.N. Dx. HAIGFNil/Res. : at 30 (1994:

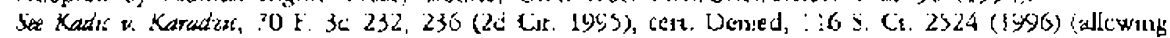

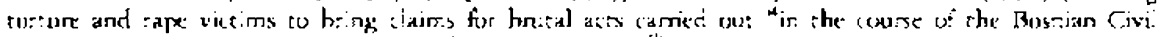

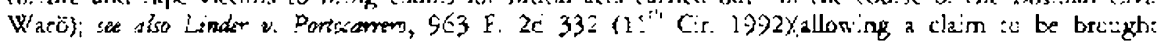

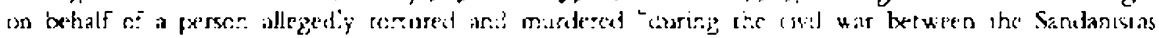
anc the corress in Niri:agua).

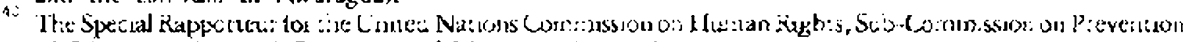
of Disc:imination and Protection of Kinnt.ties has writ:en:

The Special Aapporte's reirerates thas in orde: to end irsporicy ścr gross volations of incernarionà

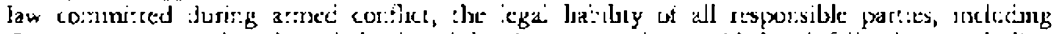

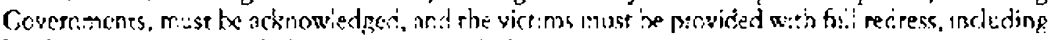
legal compensation and ent prosesurien of the perrerrators.

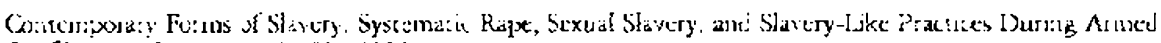
Conflic: at 9 , zaragraph 75 (1999).

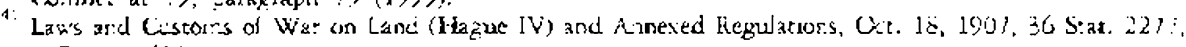

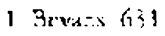

4: Ju:e $2 \hat{5}, 1539,2$ Eevans 43 .

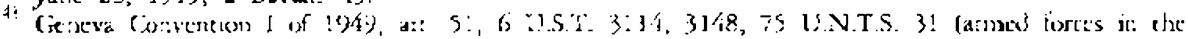

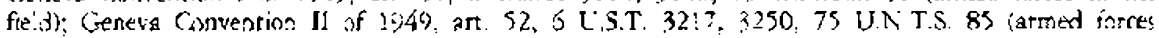

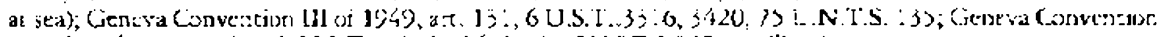

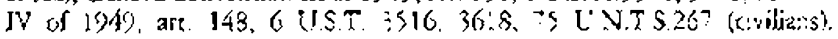

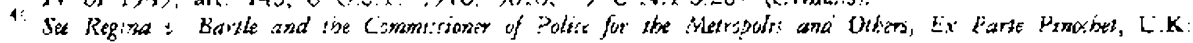
Hown of lonts (Manch i/4, :sey) 


\section{IHE OPTIONS AND STRATEGIES THA'T HAVE BEEN PURSUED ELSEWHERE}

Each. country's struggle with ets past is different, so genera'izatiuns are difficlit. But it: most parts of the world we wow scx a comraitnent to adkess bu:mar. rights aluuses, rc punish the perpertrarors of such actions, and to hring justice, ompensation: and a sense of closuse to the vicums. In those places where amnes:ies have been offered like. Chile: Argen:ina ${ }^{\text {as }}$ and Sierra eone the yearning for an acrounting reavairs and will not go away, Ir. places where she governing regime wants to put the pas: boind it and fous on building a bercer future like Cambodia the people and the international community refise to let the past be forgetten and insist on orderly investigations and proseculions.

The list of curcent effurts to achieve justice is long: and is worldwide in joographic

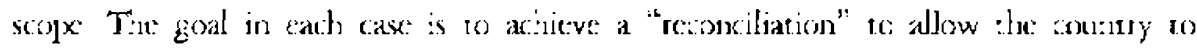
gis forward toggether, withou: always setursing wo the pas: for a reexamination resulting, from a sense of a penple wronget "Feronciliation" is a powesfi. noord It is not iust a feel-gond concegt, which ran te achieved by a fow rords of soron followed by some handshakss or hugs. It requires makirg righ: the woong that oxcurred. It recuires a full and fair arknowledgmen: of the wrong, followec by a real settlement, usually requring the rransfer of morey andor propert: and the punishment ard/or disgrace of those who compined the wrongs. it:

Ihe stritcges ucilized so bring a sense of closure and reconcliation wan lo caregurized

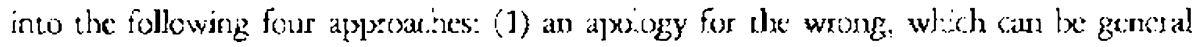
a. specife, (2) an investigation and arcouncing; (3) comperasation for the vicrime, wither through a general rass approach, or thrcugh ine:vicual detcrminatons, or horh; and (4) prosecurion of the wongdiers. These asproaches ane descrited helow, with examples from recent history:

\section{Apology}

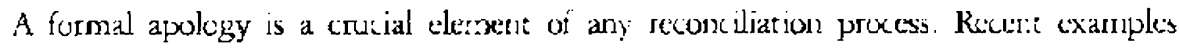

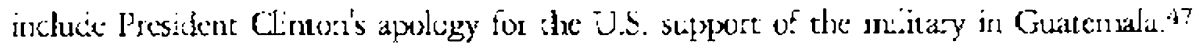

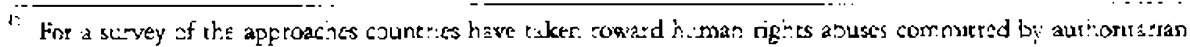

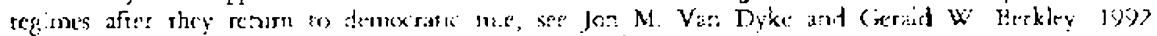

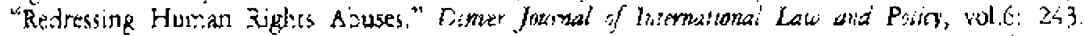

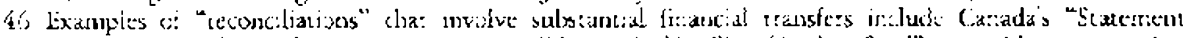

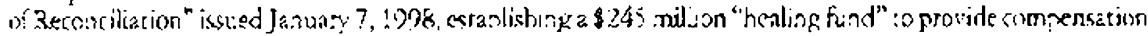

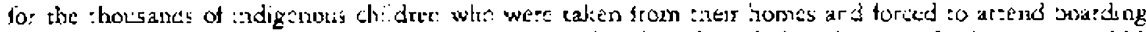

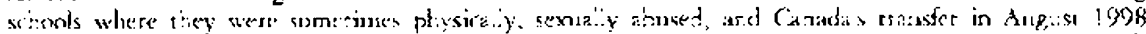

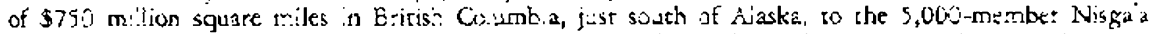

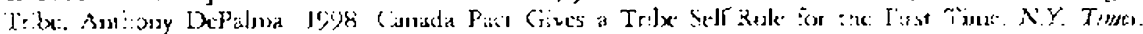

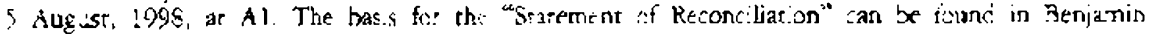

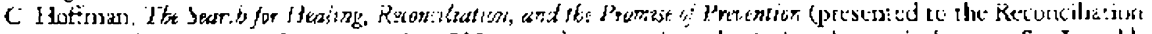

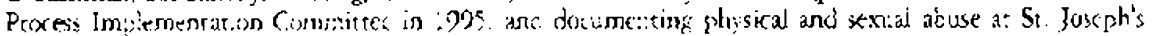

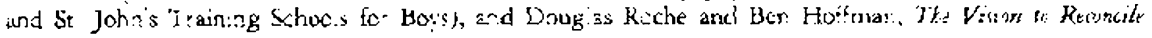
(1:i);
} 
Secretary of Srate Madeieine Aloright apologized for U.S. support for the :ysj coup that restored Slain Molammed Riza Pabalev: to power in Iran and its backing of lray during lle wat with Iran in the 1980s." Pop John Paul II issued a swexping apolegy or. March 12, 2000 for the croors of ite Roman Catholic Churct. during the previous 2,000 years, ackrowledg:ng incolerance anc inisstice toward Jrws, women, indigenous peoples, immigrants, anci the porr. ${ }^{49}$ In $: 993$, the Inired Srares apologized for the participation by its miliary anc diplonats in the illegal overthrow of the Kingdom of Hawai'i in 18\%3.5. 'The United S:ates asologized for the internment of Ja:sanese-Americans during World War li.s1 In 1999, Ausiralia acknowledged the "most blemushed chapter in our national huston;" anci expressed "its decp and sincerc regret that iadigenous Austritians suffered iajustices under the pracices of past

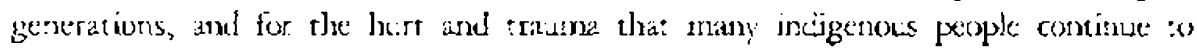

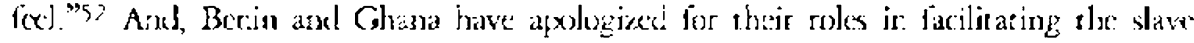
rraitc. $5 ;$

\section{Investigation and Accounting}

Docimenration of the wrongdoing se:ves the important purpose of recognizing the suffering and acknowlecging that wrongdoing cccurred. The two most significant accountings in reccr: ycars are these that took piace in Clile ard South Africa but otiners bave weclered as well.

- Chie's siruation was unicue in that General Augusto Pinochet allowed eiections to rake place in the late 19S0s, but retained sirm contro. over the military and kept a watchsul eye on the new gove:nment. The rew President, Patricio Aylwin, was effectively blocked frem prosecuting Pirushet and his military associates, but he

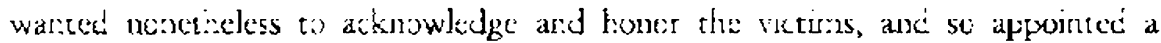
Commussios of Trut. ar:d Reconciliation which prepared a comprehensive :eport

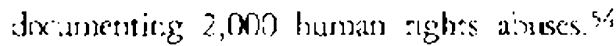

- In Soutz Arrica, a Iruth and Reconciliation Commission met for two and a balf years

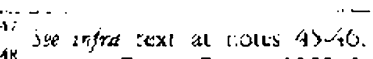

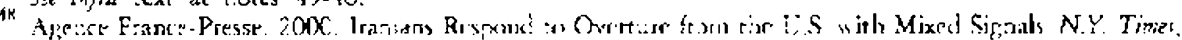
:9 Marci, at Ali, co... 1.

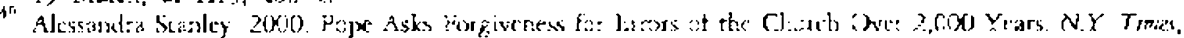

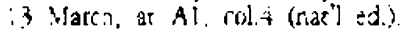

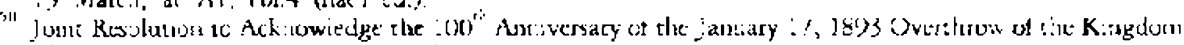
of Hawia: P :b. i. 103.150. :j7 s:at isli; (1992)

" Livi. Liberties Ac: of 1983. SC U.S.C. sec. 194\%

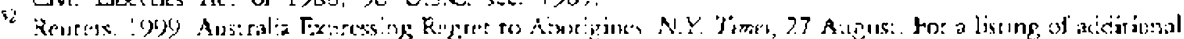

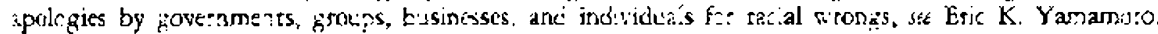

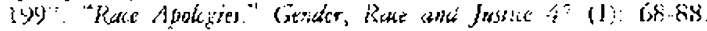

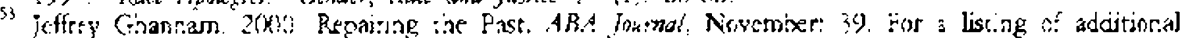

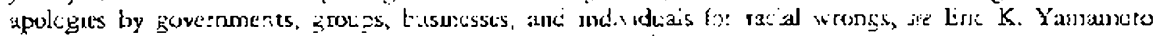

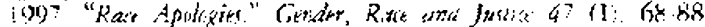

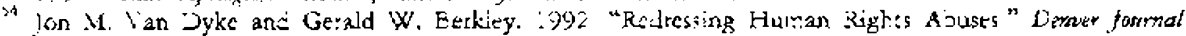

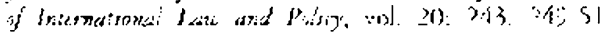


to dexunent as many of the human igh:s aisuses as possible and issued a report

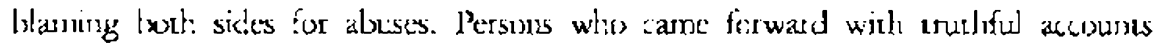
of their :articijation in velent auts liskeci to a jolitical objective wesc pardoned as past of the national healing offor, but others have been prosecuted for their role in these atroxities. 55 As of the end of $1929,6,037$ individuals had applied for political amnesty, with 568 receiving parcions anc $8: 5$ applications still uncior cons:deration 56 O. the 568 who rere pardored, $38 \%$ were merribers of the African Varional Congress, who wers seskirg to overticow the asartheic government, 124 we:e memixs of the apartineid security forces, 28 were in the Zulu-basec Inkatha Freton Party, ard onc Aciani Vlok who had ixc: Munser of Law and Order from 1986 to 199/ and confessed 10 orcicring a bomb atcack in 1987) was a menixer of dxe governing aparticeid National Pauty. ${ }^{5}$

- In Februay 1999, ar. independent Uni:ed-Vations-sponsored Historical Clarificarion Cimmission concluded ar. 18-montr. investigation and reported that the Guatemalan military witl: U.S. money and raining commattec "acts of genoxide" against the mdigenous Mayan communty in Guaterrala durng the country's long civil war

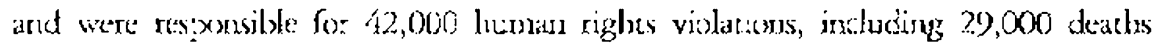

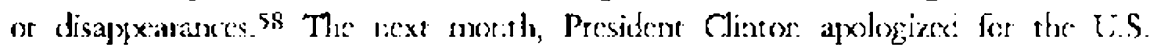
participacion say:ag thas "support for mil:ary forces and irtelligense units which ergaged in violence and wides-rear repressior was wrong, and the Initer Sraves mist not repeat that mistake." so

- The cicy of Iulsa, Okdahorna, estatslistad le 11 memaloe Tulsa 1921 Race Riot Comndision wo investigite and doxument the rampage of May 31-June 1, 1921,

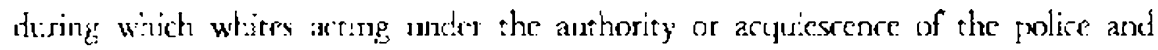
sherifis deputies destroyed more than 1,000 homes, 35 stores, eight doctors offices, and five mocels, and killed up to 300 African-Americass in the thriving black Greerwood section of Tiulsa, also calleci the "Vegro Wali Street." The Commission spent two years interviewing handreds of witnesses and victims, and in February 2600 recommenced that the State of Oklanora pay reparaticns to the 83 survivors now $n$ th:eir $30 \mathrm{~s}$ and $s 0 \mathrm{~s}$ whose eelatives were killed or whose property was destruyed.

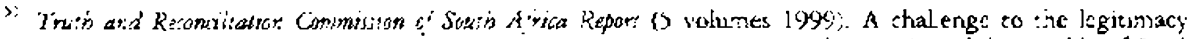

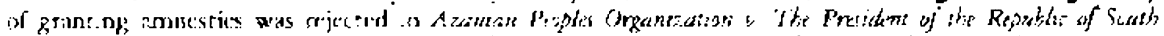

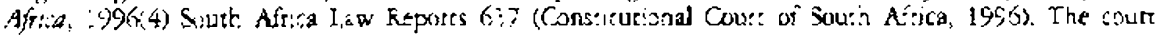

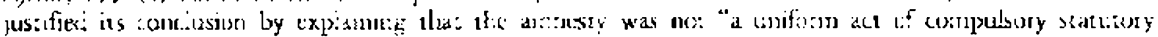

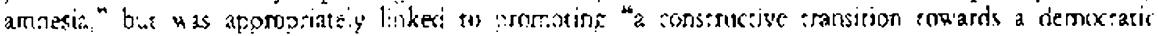

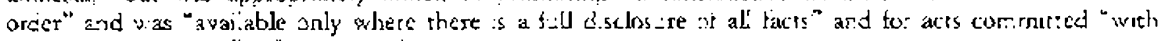

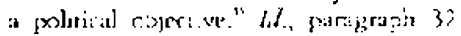

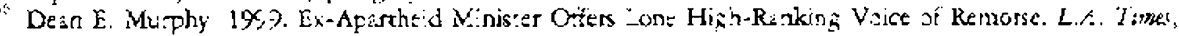

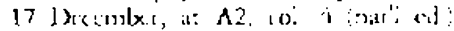

Id. onl. 5 .

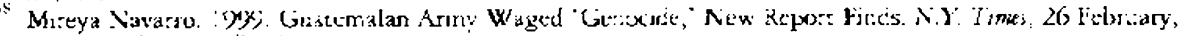
at $A l$, isl. 8 (r.ut') ad.).

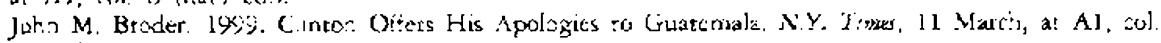
S is:itl sid.)
} 
The Commission recommencid that the state pay survors and the descendants of murder viciurs and also fund a scholassup program, establisin an enterorise eone for black businesses, and exece a monurnent to the vicirrs, a package that :night cos: as mixh as $\$ 33$ million. 60

\section{Compensation for the Victims}

International law has always been c.ear tha: reparations are essential whenever damages result from violations of in:ernational law. This principle is securely rooted in the decision of the Permanen Cour: of international justice in the Chorzou Factry Case.

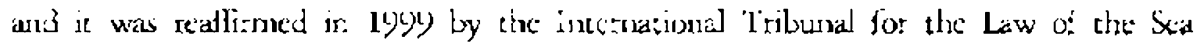
in the M/V Saiga Caier. Reparatives are just as important and ust as mandatory in

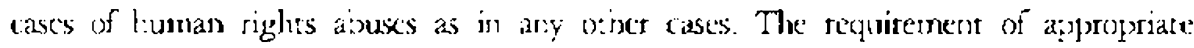
enmpensation is being resognized increasingly in a nide vatipty of contexts.

- In :992, atrer more than 2,000 human rights abuses were documerted by a Chilean Commission, blue Chilean Legislature enacted a lâw providing a wide range of

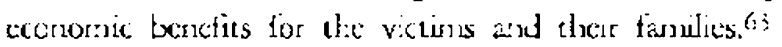

- The Japanese-Americans interreci in World $W_{a r} I_{\text {a received }} \$ 20,000$ each, 64 and those persons of Japanese ancestry brougit to camps in the United States from La:in American have received \$5,000 eacr. bs

- Carada has provided a reparations package for the First Narion cinildren who were raken trom treir families and :masfered to toarding schools where they were deried access to therr cülnute and trecuencly physicaly miszreated 60

- New Lualarsed established a process to acidress the witungs commiled by the British against the Marori people in the late bous, having systerrasically taken their lar.ds and resources, and has returiacd ande and tmansferred farrories, fishing vessels, and fishing rights to the Maari groups to compersare them for their losses. S?

- in Puerto kico, Givernor Pedro J. Ressello fublicly apologized and oflered aestitution

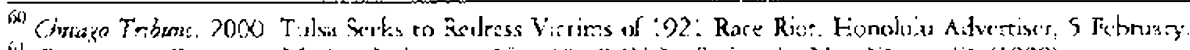

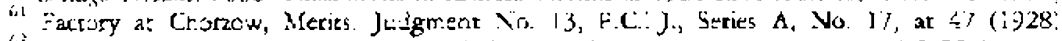

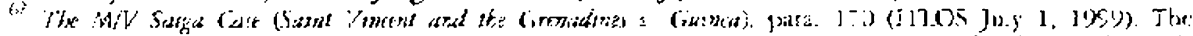

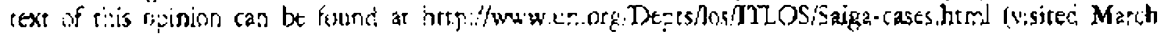
22,$2011 ; i$

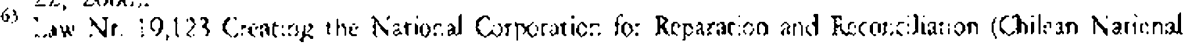
(ongress 1952).

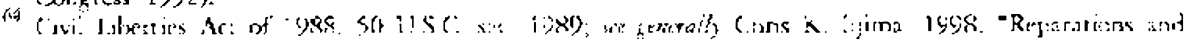
the 'Mricel Minutity' Ideo'ogy of Acue:esctence: the Nectssiry to Refust the Return to :ne Original

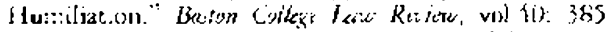

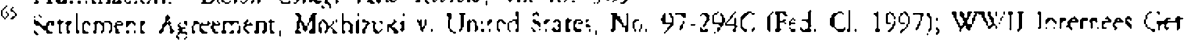

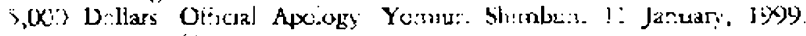

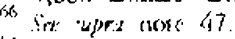

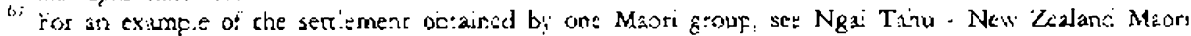

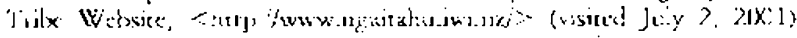


of dp : $\$ 6,000$ each to thousands of "independentistas" and others who were spied m by a police intelligence sut starting it: the late :9/0) 68

- In 1994, Florida Governor Law:on Chiles signed into law a sill providing for the payment of $\$ 2.1$ milion in reparations to the dexrendants of the black victims of the Roscwooc massacre, in which white lyncis mobs killed six blacks and drove others frem sicis homes to destruy a prospcrous slack commuricy. "S Lnder thes bili, Horica provided $\$ 150,000$ io eack of the nire survivors, and other monetary

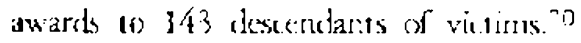

- Lansuits have been filed in the Urited Sta:es by victims of human rights abuses for compensation. One of the prominent cases was broughe by 9,500 vicrims of human rigits abues is the Philippines against Ferdinand $\mathbf{E}$. Marcos winen he was cxiled to ldawai'i ir. 1986, anc continued agannst hes estate after ix aico in 1989. A Eederal cour jury rule: that Marcos was liable for torsare, ururder, and

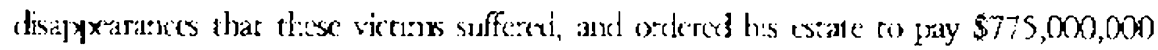
in compensatery darages and $31,200,000,000$ in exempiary damages. $i 1$

- The German government has funded various compecasarion prograras io fay victims of the Worla War II lioluausi, and is make paymests directly to the Siate of lsrael as well. ${ }^{72}$. More recertly, lawsuits were alled in U.S. coures by inc victions of slave- ant forced-laber dasting Wotd War II aganst the Coeman banks arms inmpanies that profited from such ajouses, ${ }^{37}$ ard is the summer of 2000 a formal agreeren: was reacted as srovide $\$ 5$ : billicn ro the 250,000 members of this vic:imuzed class.74 Payments of about $\$ 7,500$ :0 each person forced to work as a slave laberer and abour $\$ 2$ :500, to each person obliged :o woik ir forced-labor siruations began to be cistr:buted in the surmer of 2001."s

- Auseria has smilarly establisher: a \$00 : $\$$ ilion fund to provide compensation to slave and :orced latorers sent to Ausstria by Hirier after the 1938 annexation.?

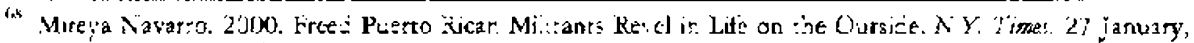
al A.4, :ol ; (n:at'l : ‘d)

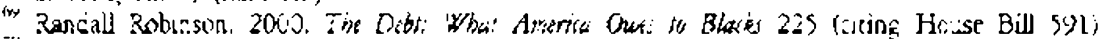

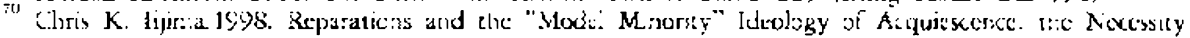

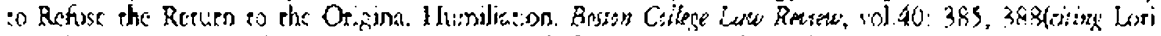
5. Rabunson. 99: Richtirg a Wreng among Bleck Ames.cans the Debare is Escalatıg over shether

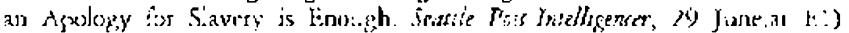

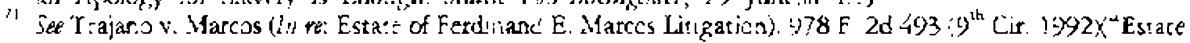

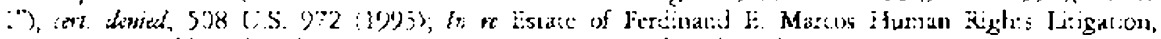

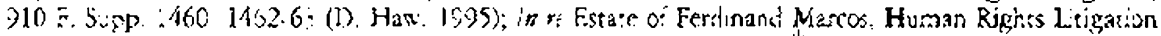

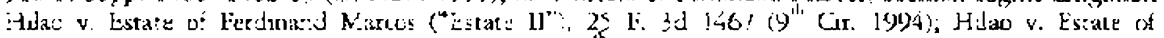

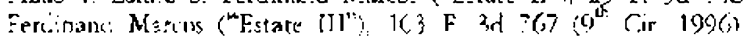

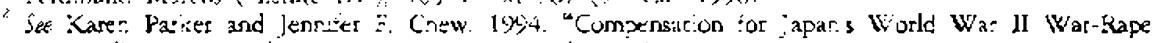

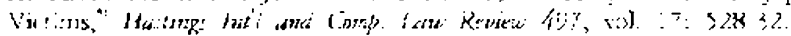

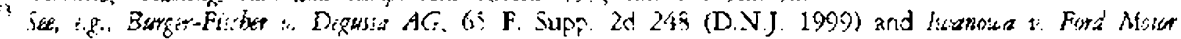

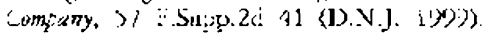

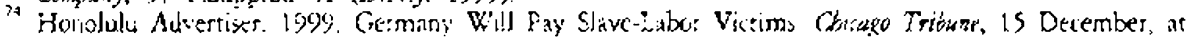
. 11.

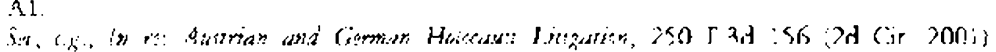




\section{Prasecution of the Wrongdaers}

The Trials at Nuscmle:g and la tre Fur East after World War II still stand as mox.cls for systemaric and conscientious prosenuricns of those who have violared rhe laws of war and fundamental haman ights principles. But for almost half a century aiter those trials, no other interna:ioral trials sook p.ace. Then ir the early :990s, the United Nations Seclirity Counc'l established tribunals te prosecute those who viclated fundameatal norms during the fighting in the former Yugoslavia and Ra:anda $i$ lhese rr:burals were slow in gerting sta:tec, but have recently xeen procedirg steadiy through

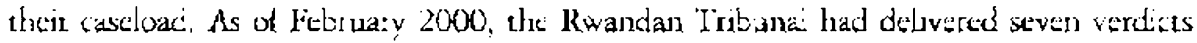

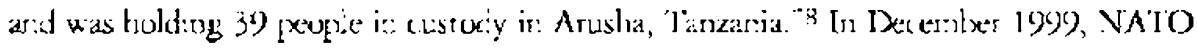

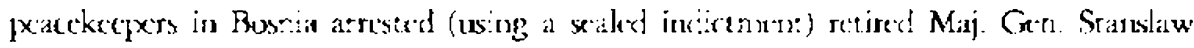
Galir, who had commanded the Bosnian Satb forces that besieged Sarajevo trom 1992 to $1904^{-10}$ In June 200 , the Sartian government Sinal'y extradited S'ohodan Milosovir, and fiew hirr to the Nethetlards so face rrial. In January 2000, IIS. courts cleared the a ay Sor Elizaphain Niakinu:imaxa to be turned vier so the Rwandan tribunal for prosecution. He was a church leader accused of offering refuge to ethnic ruesi and then turr.ing a Hutu death scuaci loose on them, ${ }^{80}$ Then, in Febriary 2000 , three high-anking liwandan officers were alrested in Eurepe cn warrants issued by the Rwandan I'ilsunal. : ]

- General Augusto Pinxchet, the ruth.less diccator of Ch.le arora 1973 to 1989, was held under house arest in Eagland for :6 months, fightirg his extradition to Spain to be prosecuted for the tortare anci mi-der of Chileans, but he was finally retumed to Chile in February 2000 after british vificia's conciuded that he was medically;

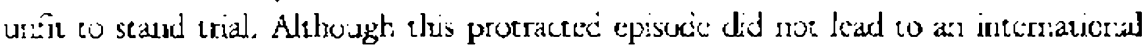
trial of P:rocnct, the Bersist I Iouse of Lords reachad a signinicant decision turing

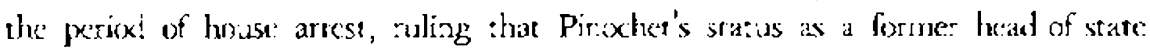
did no: give him an inmunity from prosecution and that prosecurion for his egergious "universal" crimes woulc be approptiate is any country. Sirce his return, Chi:e's

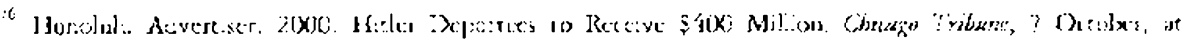
A.

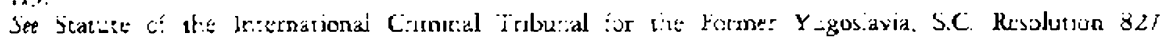

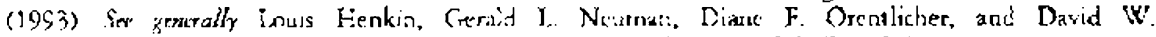

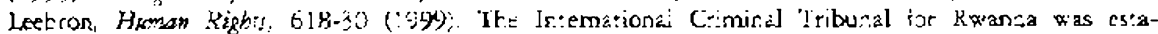

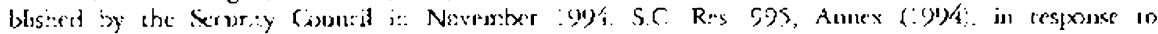

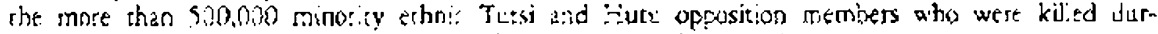

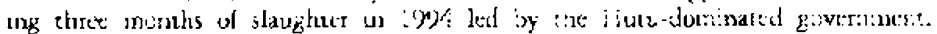

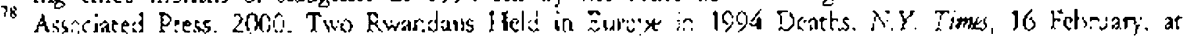
A6, col. 6 (cat'l ed.)

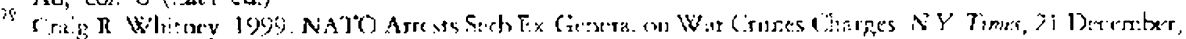
at $A$ ilo, col. 3 (:at'l ed.).

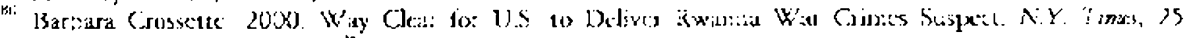

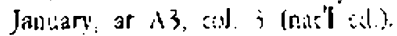

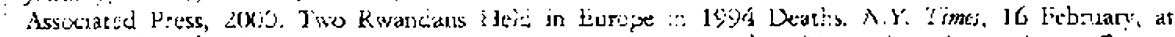

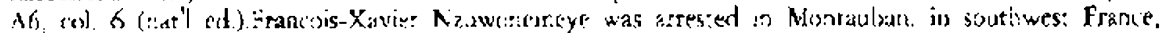

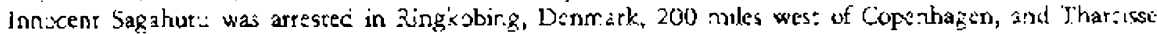

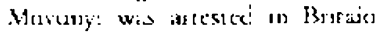


cowrts have concluded that General Pircoher is not entited to immunity, and are alsc pursuing cases against militaty officess who served in the Puncthet government.

- In Novamber 1999, Judge Baltasar Gazzon, the same Spanish magistrate who has becn pursuing General Pinochet, charged 98 former Argentine officers with genocide, terrorism, and corcure in connecion with the arrocities perpetrated b; the military dictatorship that controlled Argenuma trom. 1976 to 1983, wherc berwecn 9,000 anc 30,000 persons cied or deappeared." Previously, Judge Garzon ordexed tix

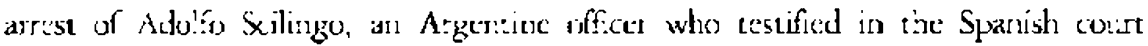
that he had thrown disside:es from planes diring the Argentine "diry war." 8 a Jorge Rafarl Videla, the Argen:ine dictater during this period, was rearresned in Jure 1998 for his pariciparion in the systematir kidrapping of chilcrer, even though he had previously been pardeneci (ir. 1990) afte: $t_{\text {in }}$ life sentence (in 1985) for his tole if the death scuach tú In Febriary 2000 , Argentinas newly-inaugurated President, Fernando ce a kua, ordesed a purge fror. the government payroll of the some- , SCO military personrel and civilians connected with the "diry wrar" from the 15)?6-85 periced 8

- Brazil is finally adziressing the abuses that occurred during the military dictatorstrip tha: lastec from : $\$ 64$ to 1985 . A new investigacion is underway to deresmine what really happened on April 30, 1981, when two military xersonnel were kilied by a boms in the parking lo: outside ar. arena containing 20,000 supporters of left-witg calses, to determunte whether they werc agent provkatem trying o disnipt :he cvent; and the numianation of Jcao Batista Carnpeto as de dief of the Foderal Police was derailed recenty when it was revealed that he had supervised torrure in 1970.76

- The Uritec Naticns jas been arterr.ptir.g to negoriate with Canioodia to establish a genocide tribunal tha: would be poncly rir by the inired Nations and the Cambodian government. Under this afproach, trials would be hed for a the top Kl:me: Rouge leaders, whe were responsible for the dea:lss of some 1.7 millou Cambodians who werc exccuisd or cied of starvarion or disease during the 1975-79 ryme. ${ }^{57}$

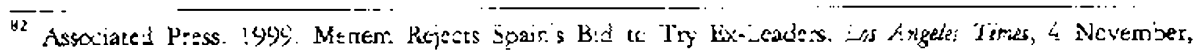
at $A$ s, $<i l .1$

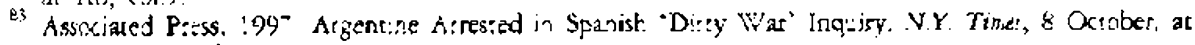
At, col. 3 (::ai'] ed.).

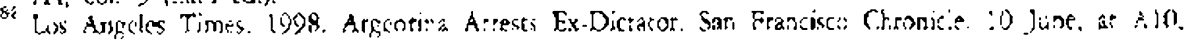
-ol.!.

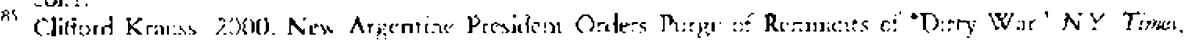
16 rebriary: at $\mathrm{A} 12$. col. 5 (nat'l ed.\}.

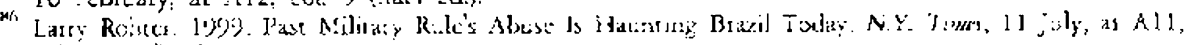
(i)l. I (not'l ab).

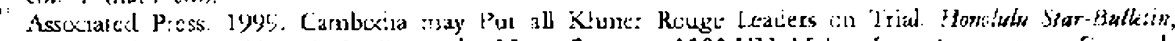

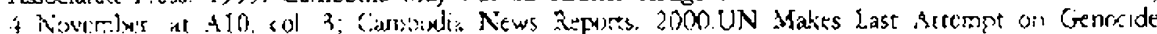

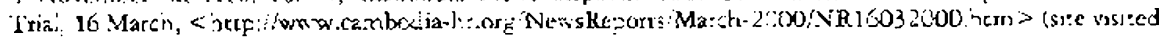
July: $3,2(1):$;
} 
Thest many si:uacions illistrate the complexity of these issues. International aw has confrined tiat every victim of a human righis abiss has the rigint to an effecive remedy, and that such a remedy wil gencaliy include the right: to a thorough investigation, compensation for the injuries suffered, and prosceution of the per petrator. But the cifferen: fac:ua! siruations listed above teronstrate that no one approact. wotks for every instorical event. Just as prosecutors exe-cise discretion to refrain from prosecuting in certain s:tuatiors, and : 3 arcept pla agreements for reduced charges :In many other situations, soree histo:ical ep:sodes seen to justify a merciful approach, with reduced perialties or simbly a full cescription ce what astually happened. In scric stuatuons parcions appeat of $b$ justifiec atter part of the sentence has been served tc feses mationa: healeng. But in cac: sicuation, as an irreduc:ole minumbin,

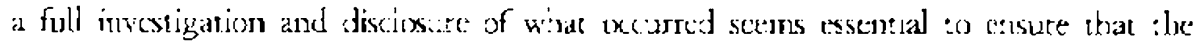
culprits' deads are known by al. and to grexem: them from exer exercising jower again. For a true "recencilation," the transfer of prosery from those whe have bencitot to those who have suffered seems essential to bring the matter to a ji:st and acreptasle resolution.

\section{THE INTERNAIIONAL CRIMINAL COLRT'}

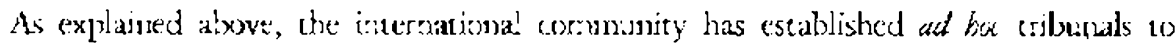

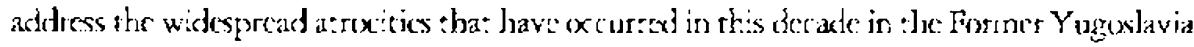
and in Rownda. They have functionec effectively; afrer faltering starts, and row are trying to incict criminals in a systematic anci ordesly fashicn.

In onde: to avoid having to estabish a new cribuinal every time an intenational crisis ocuss, ealigntened diplomats came together in the summer of 1998 to drit a treaty; tc establish a permarient International Crinuzal Colit.89 On March 8, 2000, the Repujlic of Korea bexame the ys ${ }^{: 2}$ country so sign this areaty, anci 115 counerses har signed by

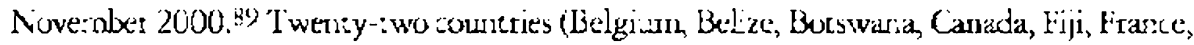

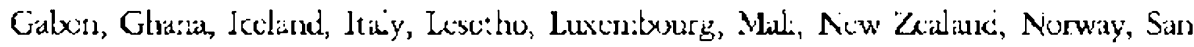

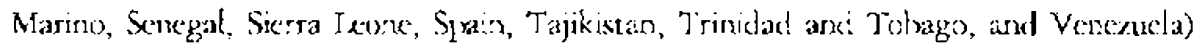

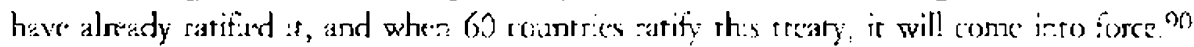
linder his treary, crimes agains: hu:manity: genocide, and war crimes 91 would be subject to tre jurisdiction of ine intenacional tribuinal in situations the:e rational courts are not able to prosenize these crimes, as decermined by the Lnited vations Securty Council or the Court's Prosecuror. No longer would ad bor trijunals tave to be set up each time a horreadous crine agains: humanity occ.srs, with all the atendanr

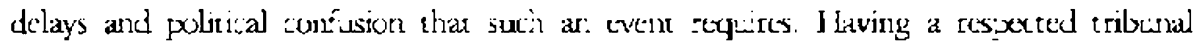

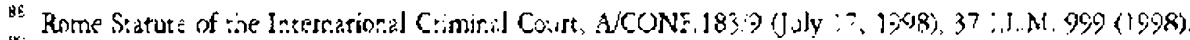

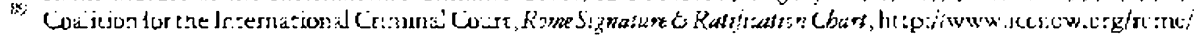
\% hrid.

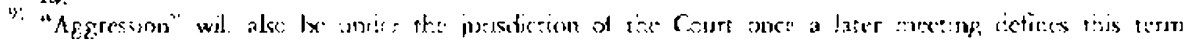


in place would allow the incernational community to work rapidly to put the fol pors and sicidam bisscins on tric ir a tair anc expedious ramber.

\section{CONCIISION}

I ow can a soxicty build a future if it is stil. pxiscred by the past? If somerome has killed your spomse or your child, is it possible to forgive and forget of is the innate need tor istice -- in lucing, punishmert, rompensation, and a fical arcounting -- too strong to set aside?

Some argue that countrues returnirg to democracy after a period of authortarian rule shoulc forego investigations and prosecutions of human cigiots abisers in order to promote the seaing anc nation-buld ling process Thoy algut that protracted trists will cxacerbate ite wounds that ivided the count:y, and that the transition to

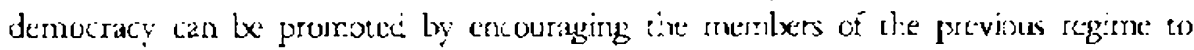

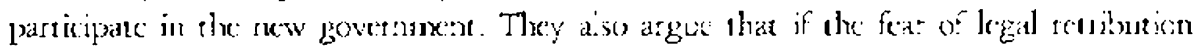

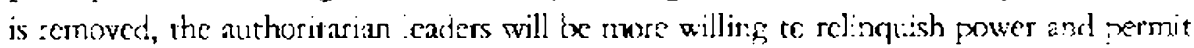
the new demorrary to incion.

These arguments freciuer.ty have a short-cern appeal, sut in the lorg an it. wil always be berte: to conduce full inves:igatiors, prosecute the abusers, and enable the victims to rece:ve appropriate compensarion. In ary orderly civiizec sociery: prosecution o: criminals is an essential responsibilizy, and disclusure of historical evernts is an important aspousibili:y of ary governuem. liach vicim has a right to know what hapixand and a right to compensation for their injures and sufering. The orderly

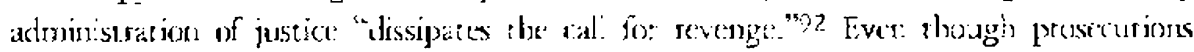
may $b_{x}$ disnuptive in the short an, they at:" nerossaty to serve to deter future auman rights abuscs Altheugh partons and plea agreemerss may he appropriare in some situations, it is never legitinate to ignone atrociries.

Li: the nacioral cours of the country where the abuses occurrec are functionis.e property and can conduce the prosecations and de:ermine the claims for compensation, these national courts snocld be given the responsiblit; to do so. But ir: some sinuasions,

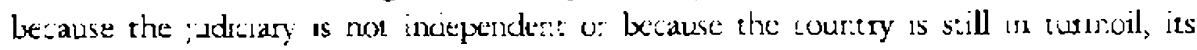

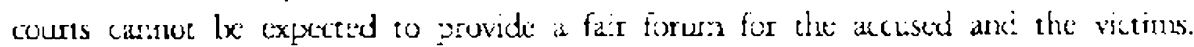

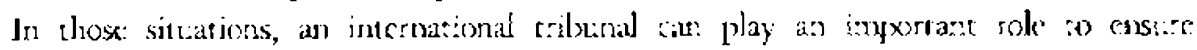

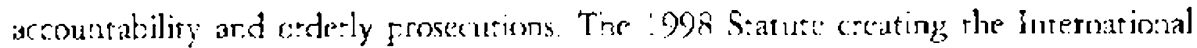

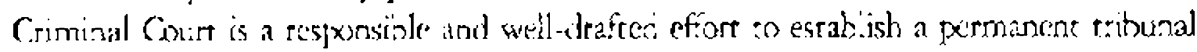
that will be avalable for such situaticns.

It is possible that the 60 atificarions netded to oring this afw Coure inco existence will be reached about the same sime as the reunification of the two Koreas, in which case the new Court could exercise urisdic:on over some of the hurnan righes abuses that requete adjudication. If not, it will tall on the courts of tixe reusidjed Korean

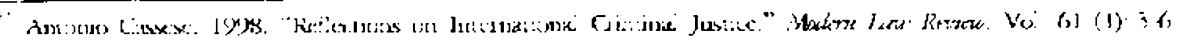


government to adctess anc resolve the humar rights violations that ocurred pnot to reunification).

\section{REFERENCES}

Agence France Press. 2000. Iranians Respond to Overure frem the L:S. with. Mixed Signals. Ver Yoré Times. I9 Marh ar A:3, col.l.

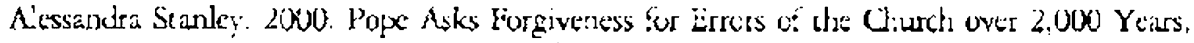
Veu York Time! 13 Mastl, at A! (ne:'l cil)

Amnesty internat:ona!. 260). Amnesty In:ernational [ Irges Korean I aaders June 26 . (http://

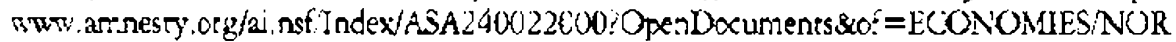
IHKOKIA;

Ammesty intmat:ona', 3000. Nerth Kurean Shot Dead at Rissians Bordes by Nond Kurcan ()ficials

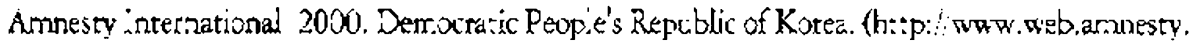
org/reb:ar2000web.nsf/courtries) (site visited Nove:nler 5, 2000)

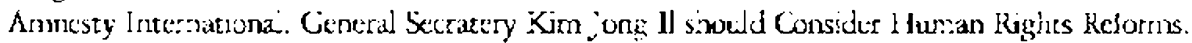

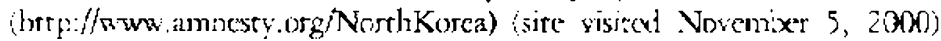

A.thcny De Palma. i 998 . Canada Part Gives a Tribe Self-Ruie for the Frast Time. Neru Y'mé Times, 5 Auguse, ar Al.

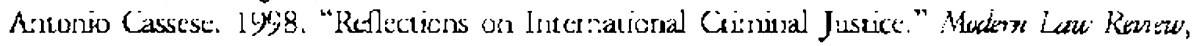
Visl. 6) (1); 3- -

Associared Press. : $X 7$ ?. Argentine Arrested in Spanis' 'Dirty War' Inquiry. Nizu Yomb Timer, 8 October, at $\mathbf{A} 4$.

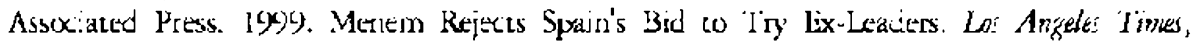
4 Novemilx's, at $\Lambda G$.

Assoxiared Press. 1999. Camiond:a may Put all Khmer Rouge teacers on Trial. Homilulu Stay-Buliktin. 4 November, at A10.

Associated Press. 2000. 'I'wc Kwandans Held ir. Europe in 1 (5x) Leaths. New York limes. :6. :bruary, at $\Lambda 6$.

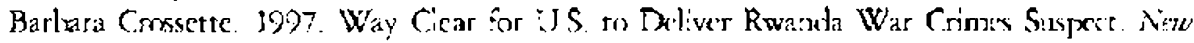
York Times. 8 Octcier, at A4.

Benjamin C. Hotman, 1995. "Tae Search for Healing, Reconciliarion. and she Promise of

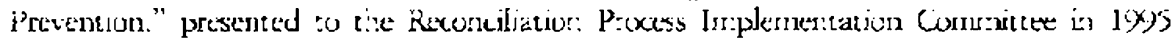

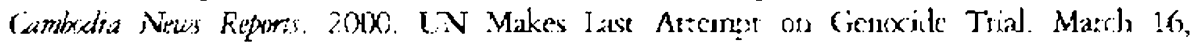

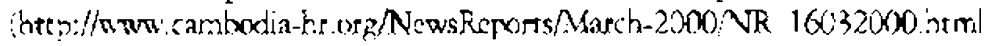

Cisis K Ijjirra. 1998. "Reparations and the 'Mode. ALnorty" Ideology" o: Acquiescence: The Necessizy tc Refuse the Retan :u the Original Hurviliation." Bistm Cullege Law Kenew, Vol. 10: 385 .

Cliffurd Krauss. 2006: New Argentir:e President Orders ?urye of Remnants of 'Dirty War.' Vew Yorie Timei 16 Feisnary, at $A 12$.

Coalition sor the Internationa: Crimiral Cour. Kome Signature and Katification Chant. (htcp://

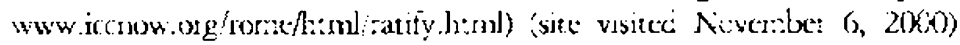

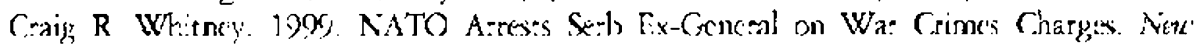
I'mk Times, 21 Decemizer, at $\lambda \mathrm{JU}$.

Jean E. Murphy. lWy9. Ex-Apartheid Ministe: Offers Lone High-Ranking Vuice of Remurxe. 
Las Angth Times, 1T Lxcenixer, at A2.

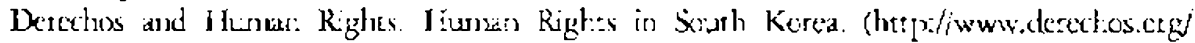
kumnan $\cdot \mathbf{r}$ (ghhts/nasia/skorea.html)

Douglas Roche and Ben Hoffman 1993. The Vismo te Recrncite (Fund for Dispure Resolution, Ontario, Canada:.

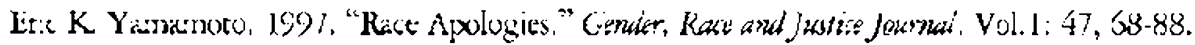
Eurepcan Colit of liuman Rights. Golder Case, Ser. $\Lambda$, ne. 18 at 17 (May 7: 1974).

Fa:tory a: Chorzow, Merts, Juckmsnt No.13. i928. Permanent Court o* International Justice, Series A, No.l?, at 4 ?

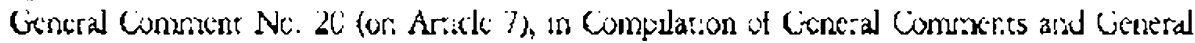

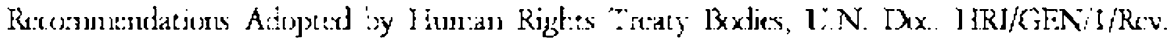
1 at $30(10 \%)$

Geneva Conventica I of 1949, ars. 5:, 6 U.S.T. 31:4,3i48, 75 U.X.T.S.3: (ammed forces in the feld?

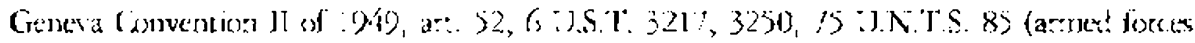
at sca)

Geneva Canvention Ill of 1949, ant 13:6 U.S.T. 33:6, 3420,75 L.N.T.S. 135

Geneva Convention IV of 1949, att.148,6 LIS.I. 35:6, j618, 35 L.N.T.S. 26: (civilians).

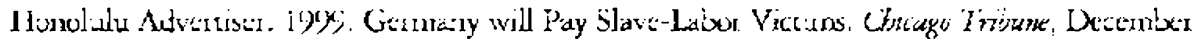
5 , at $\Lambda 1$.

Honolulu Advertises. 2000. Tulsa Serks to Recigess Vicrirs of 1921 Race Rior Chicagi Tribune, February 5.

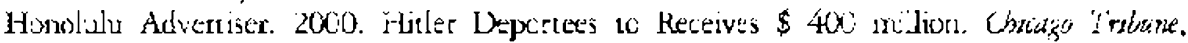
Oreolixe 7 , at A3.

Howard W. French. 200:. Japaness: Press Noreh Korea on O.d Kidnappings New Yrote Timi, 15 Octuber, at 16.

Irterrational Lega. Mater:als. 19:0. Art. 2), American Consention on Himä Righrs. Viol. S. p. 63.

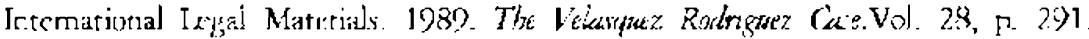

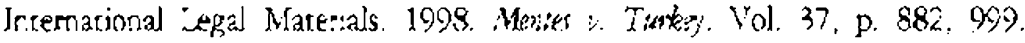

Jeffrey Ginanram, 20). "Repairng the Pas:." ABA Jritmai, November, $p .3 \%$.

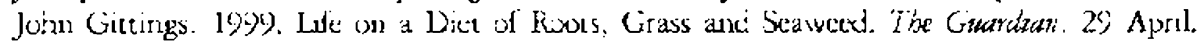

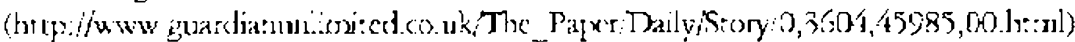

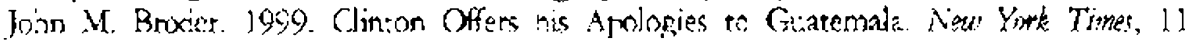
Warch, at $A 1$.

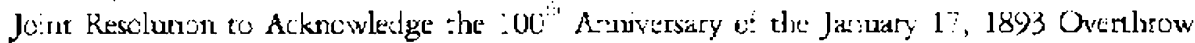

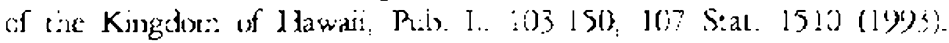

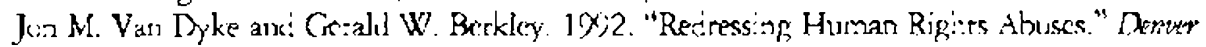
jommal of hivernational iaw \& Polic, vol 20: 243, 249-5:

Juliet Hinde.. 1998. Secrer Film Shows p.ughe of Starvieg Children in Nerm. Daily

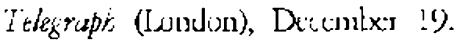

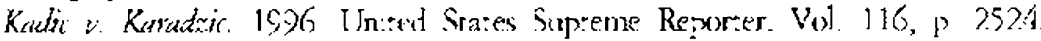

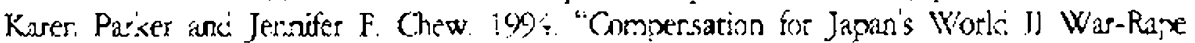
Victums." Hastinits intl and Cont. L. Rev. Voi l: 49/, 528-32.

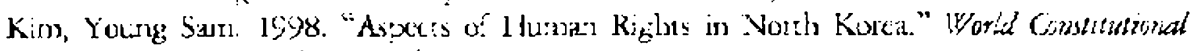

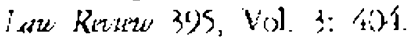

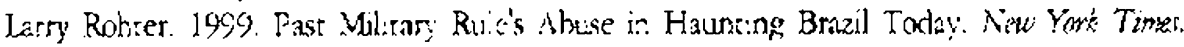
11 July: at Al:. 
Laws and Cisioms o! Wiar un Land (Hagoe IV) ard Aanexed Regulations. 1997. United State: Statute!, vil. 36, p.2277, l bevums 631.

Jori S. Robinsor. 1997. "Righting a Wrong among Black Ame:irans, the Debate is Esca.ating cver whethe: ar. Apology for Slavery is Er.ough." Seuttle Past-inteiligenuer, 29 June, at El

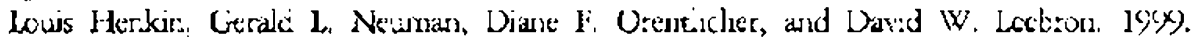
Humin Rigints 618 30 .

Mireya Nava:m. 1999. Guatemalan Army Waged 'Gonocide,' Nex Report Finus. New York Times, 26 Fetnary, at Al

Mireya Navarro. 2000i. Freed Putrto Risan Militants Reveal in Life on the Outside. New York Times, 27 January, as Al4́.

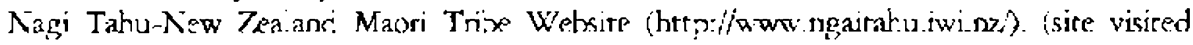
july 2, 200:)

New Yrok Tinits, 1998. A New Kind of Leacier for Sout:: Korea and for the kest of Asia $\because$ ov. liebruary 23 , at AD.

Nichoias Elberstadt. 1999. The End of Nont Kores 66. Washingror., D.C.ATEI Press.

Randail Robirson. 2000. The Debr: What American Owes in Blaciss 225. (ciring House Bill 591)

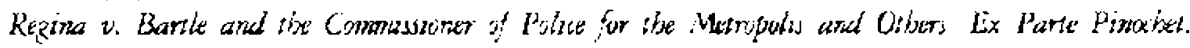

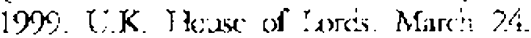

Reuters. 999 . Australia Fxpressing, Regret in Aborigices. New York Time, ?7 August.

Roger Coren. 1999. Yerder in Bedin Wan Deatrs is Upreld Nuw Yot Tims: 9 November, at $A 10$.

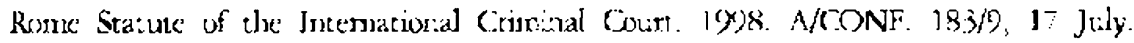

San Francisco Chronicle. OSy. Argentira Arrests Fx. Dectaror. Ias Anpeler Time: 10 Jure, at Al.

Setriement Agremen:, Mocizuna y Untec States. 1(x)7. No. 9i-204C (Fed. (l.)

Supreme Coure Repo:ter 19\%6. Vo. 116 , p.2524.

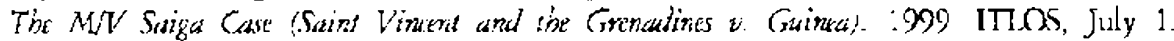

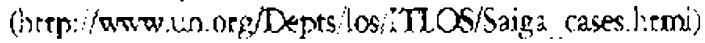

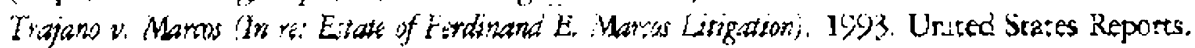
Vul. 508, p. 972 .

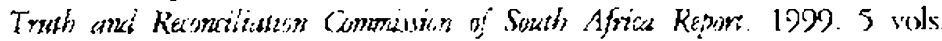

Lnired Nations General Assemisiy. 1948. Liniversal Declaration of Human Rightes. Res. 217, Jo December.

Linted States Cocke. 1983. Cini Lowner Att of 1988. Vol. S0, section 1989.

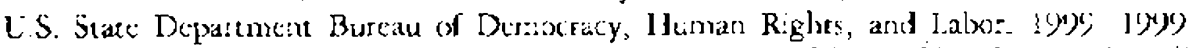
Country Reoxorts on Humar. Rights Practices-Democaric People's Rroubic of Korea. (hetp:l/) זww state.gov/uwwiglobal buman_igh:s/1999 hrp reporinorihkcr.html)

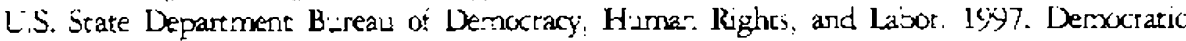
Pevple's Republic of Korea Repert on Human Kigles Practices for 1:y)? (botg:/ /www statc.

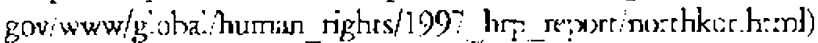

LS. Srate Department Bureau of Deriocracy, Human Righrs, and Labor. 1999, 1999

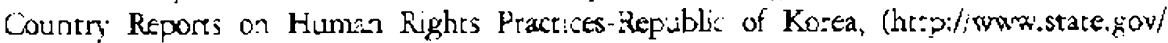

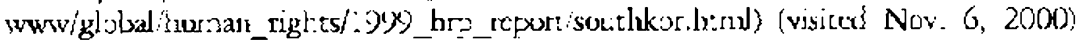

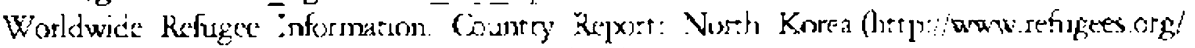
world/countrytpdeasia pacific/north koreahtrml: 